\title{
Demographic Trends, Young People's Attitudes towards Marriage and Socio-economic Changes Related to Family Formation in Greece and in the European Union: A Comparative Analysis Based on Official and Survey Research Data
}

\author{
Kostas Rontos $^{1}$
}

\begin{abstract}
:
The study is dealing with the evolution and the current patterns on marriage and family formation in Greece, as well as the related young population matters, by analyzing the demographic trends during the Post World War II, the temporary attitudes and behavior, especially of young people and the socio-economic factors associated with these trends. To meet these tasks, secondary and survey data are employed, demographic indicators are constructed and descriptive plus non parametric statistics are used.
\end{abstract}

The similarities and differences across Europe are identified as Greece is partly following the southeastern demographic pattern and attitudes towards marriage and family formation, but also the particularities even from the other Mediterranean-Southern countries.

The demographic and attitudinal differences among societies are due to the different time period that each of these passed through the certain phases of social and economic transformations.

Key Words: Demographic trends, - Attitudes towards marriage- Age at marriage -FertilityGreece and Europe- Socioeconomic explanatory factors- Female University students.

\footnotetext{
${ }^{1}$ Associate Professor of Social Demography at the Department of Sociology of the Aegean University
} 


\section{Introduction}

In the post World War II, demographic trends moved worldwide towards a certain direction with the falling marriage rates, the higher the age at marriage, the declining fertility and increasing divorces, as the main characteristics. Due to the demographic variables' interaction, these trends led to a considerable decrease of young people and to an ageing population, with serious negative consequences on the socioeconomic and political aspects of society.

These trends seem to be universal, as Adams (2004) indicated, taking place not only into the western developed societies but also into the less developed eastern and other societies. Of course, differences among the several regions of the world exist and exceptions within a certain region are also presented. As Fussell and Palloni (2004) pointed out, demographic measures of family formation are hardly changed in Latin America during the last 50 years, despite the considerable economic, social and political transformations.

In Europe, these demographic trends are present but considerable differences exist in a cross-national level, as indicated in several past (Dixon, 1971) and present comparative studies (Oinonen, 2004, Kalmijn, 2007). Recent research shows that, in more traditional societies, such as in southeastern European countries, people get married and bear children or live as singles with no children. In northwestern European countries another pattern is developing, where couples prefer cohabitation with a fertility rate similar to that among matrimonial unions (Pinnelli and Di Cesare, 2005).

In this territorial context, the present study focuses on the demographic trends of Greece, being a typical southern-Mediterranean country and they are examined in comparison to eleven selected southern European countries and other regions of Europe, as determined by Kalmijn (2007).

\section{Research Methodology}

The analysis is based on demographic data and indicators, constructed by us or retrieved by National Statistical Service of Greece and Eurostat. There is also a necessity to analyze the attitudes and the behavior of the society, and in particular, of the young people, towards marriage, cohabitation or single parenthood and their relation to the fertility produced by each of them. Moreover, the way of how the above situations are connected with the emancipation of young people is of great importance in the study of youth (Merino and Garcia, 2006).

Relating the changing demographic behaviour of Greece to the relevant attitudes we expected to see if the former happened due to the changing patterns of the later or if the attitudes towards marriage itself remain positive and the postponement or finally the cancelling of marriage and childbearing is affected by attitudes towards work, 
use of leisure time, money, education attendance and sex roles. Attitudes towards cohabitation are also examined in this study in order to contribute to the numerous research works to measure and model this informal marital status (Rodriguez, 1998, Manning and Smock, 2005).

From the 6 types of cohabitation suggested by Heyveline and Timberlake (2004), the present study is dealing with the type "alternative to marriage", studying the possibility of people living together but outside marriage. The preference to being a single parent is also a situation outside marriage, which is also examined, as well as, the impact of negative attitudes towards marriage, and, of the older age of marriage on fertility.

Marriage is not only a significant social fact but also a basic demographic factor, as a considerable number of births still come from married couples. As a consequence, the reduction in the number of weddings, as a result of changing attitudes towards marriage, single life or cohabitation, or marriage at a later age, or even single parenthood, has a considerable negative impact on the fertility rate. Seltzer et al (2005) regards the increasing number of children born outside marriage as a serious factor towards fertility decline, while for Spain Munoz (1995), indicates that fertility rates of younger unmarried people have fallen in comparison to older age groups. As the impact of age at marriage on fertility is concerned, especially of women, relevant studies have indicated that the older the age at marriage, the bigger the fall in fertility, as older women attempt to have their first child later, with lower chances of maternity (Mosher, 1988, Tomes, 1985, Pinnelli and Di Cesare, 2005).

The above attitudes and behavior related to marriage and family formation will be analyzed using data from two sources. First using data from the World Values Survey of 1999 and secondly using data from a specific survey on female university students. The results for Greece will be compared, as for demographic trends, with other European countries from different regions.

The study, following the practice of other researchers (Jonson and Jaccard, 1981, Kerpelman and Schvaneveldt 1999, Hallet and Gilbert, 1997), focuses on female university students, who, as young educated women, present rapidly changing attitudes, while the men's timetable has been rather more stable during a long period of time, giving a priority to education-work and then marriage-childbearing.

The third main target of the study is to present the socio-economic changes in Greece during the post World War II and the state policy action, that are related to the demographic trends and the changing attitudes and behavior towards marriage and family formation-dissolution.

To summarize, this study was designed to present and analyses: (i) the demographic trends in Greece during the last half of the century in relation with marriage, family formation, childbearing and the evolution of young people as well as, to indicate 
similarities-differences of Greece with other European countries, (ii) the attitudes and behaviour of young people, especially of the educated female young women, on family formation- dissolution issues and emancipation in a cross national European context and (iii) the socio-economic context in which the demographic trends and attitudes were formed.

In order to meet the above mentioned targets, a comparative analysis based on statistical data follows, then, the socio-economic changes that are associated to the demographic and attitudinal changes are explained and, finally, the conclusions related to the basic trends and their causes and consequences concerning young people, marriage, family formation and fertility are presented.

\section{Comparative Analysis for Young Population, Marriage and Family Formation}

\section{Demographic trends}

The demography in Greece has considerably changed during the post World War II, as illustrated into the table 1 . The total population increased from 7.63 million in 1951 to 10.96 millions in 2001 and, as a forecast, to 11,33 million inhabitants in 2006. The share of young people of 15-29 years old has fallen from $27.8 \%$ to $22 \%$ during the last fifty years, while the rapid population ageing forms the relative indicator equal to 110.1 in comparison to 23.9 in the early fifties.

The number of marriages per 1000 inhabitants has fallen from 8.5-8 in the early Post World War II period to about 5 per 1000 inhabitants in 2006. The mean age at marriage for males seems to be stable at about 30 years, during the period of 19511991, a fact showing the life style of men in Greece, who traditionally find a job after finishing school and then get married. The average age at marriage has considerably risen to $32-33,5$ years during the decade of 2000 , indicating new factors connected with further postponement of the wedding for the male population.

Furthermore, the age at marriage of women is also stable at the age of 24-25.5 years old during 1951-1991. Recently, females, as males, do postpone their wedding at the age of 28 in 2001 and at around 30 years in 2006, which is actually a considerable changing characteristic to the family formation pattern.

The share of married people is declining since 1981, after a considerable increase of the previous time period (table 1). Married young people's share is also shortened by half during 1981-2001, showing a rapid changing behavior of a new generation towards marriage.

Cohabitation in Greece will be examined in the next section in comparison to other European countries, as Eurostat is the only source of relative data. 
Table 1. Selected demographic and social indicators for Greece, 1951-2006

\begin{tabular}{|c|c|c|c|c|c|c|c|}
\hline INDICATORS & 1951 & 1961 & 1971 & 1981 & 1991 & 2001 & 2006 \\
\hline $\begin{array}{l}\text { Population of } \\
\text { Greece }\end{array}$ & 7632801 & 8388553 & 8768641 & 9740417 & 10259900 & 10964020 & 11333999 \\
\hline $\begin{array}{l}\text { Population of } \\
\text { age } 15-29 \text { as } \\
\% \text { of the total }\end{array}$ & 27.8 & 24.7 & 20.6 & 21.5 & 22.2 & 22.0 & $\ldots$ \\
\hline $\begin{array}{l}\text { Aging } \\
\text { indicator }\end{array}$ & 23.9 & 30.6 & 43.0 & 53.7 & 71.1 & 110.1 & $\ldots$ \\
\hline $\begin{array}{l}\text { Population of } \\
\text { Metropolitan } \\
\text { areas as \% of } \\
\text { the total }\end{array}$ & 22.0 & 26.6 & 35.4 & 38.4 & 37.2 & 36.3 & $\ldots$ \\
\hline $\begin{array}{l}\text { Employment } \\
\text { in primary } \\
\text { sector \% }\end{array}$ & 48.1 & 53.9 & 40.6 & 27.4 & 17.3 & 13.0 & \\
\hline $\begin{array}{l}\text { Women with a } \\
\text { University } \\
\text { Degree per } \\
1000 \text { women } \\
\text { of age } 15+\end{array}$ & 6 & 9 & 18 & 26 & 59 & 92 & $\ldots$ \\
\hline $\begin{array}{l}\text { Women of age } \\
15-29 \text { with a } \\
\text { University } \\
\text { Degree per } \\
1000 \text { women } \\
15-29\end{array}$ & 6 & 10 & 21 & 39 & 74 & 89 & $\ldots$ \\
\hline $\begin{array}{l}\text { Economic } \\
\text { active women } \\
\text { per } 100 \\
\text { Women of age } \\
10+\end{array}$ & 15.8 & 33.5 & 23.9 & 22.7 & 26.8 & 34.7 & $\ldots$ \\
\hline $\begin{array}{l}\text { Economic } \\
\text { active women } \\
\text { of age } \\
15-29 \text { per } 100 \\
\text { Women } 15-29\end{array}$ & 27.4 & 47.6 & 32.4 & 33.2 & 40.3 & 45.3 & $\ldots$ \\
\hline Marriages & 63256 & 70914 & 73350 & 71178 & 65568 & 58491 & 57802 \\
\hline $\begin{array}{l}\text { Marriages per } \\
1000 \\
\text { inhabitants }\end{array}$ & 8.27 & 8.44 & 8.31 & 7.32 & 6.39 & 5.34 & 5.18 \\
\hline $\begin{array}{l}\text { Average age at } \\
\text { marriage } \\
\text { (males) }\end{array}$ & $29.8 *$ & 30,1 & 29.55 & 28.97 & 30.03 & 32.30 & 33.41 \\
\hline $\begin{array}{l}\text { Average age at } \\
\text { marriage } \\
\text { (females) }\end{array}$ & $25.0 *$ & 25,3 & 24.05 & 23.77 & 25.51 & 28.15 & 29.69 \\
\hline Births & 155422 & 150716 & 141126 & 140953 & 102620 & 102282 & 112042 \\
\hline
\end{tabular}




\begin{tabular}{|c|c|c|c|c|c|c|c|}
\hline $\begin{array}{l}\text { Births per } \\
1000 \\
\text { inhabitants }\end{array}$ & 20.31 & 17.95 & 15.98 & 14.49 & 10.01 & 9.34 & 10.05 \\
\hline $\begin{array}{l}\text { Total Fertility } \\
\text { Rate }\end{array}$ & 2.63 & 2.41 & 2.30 & 2.12 & 1.47 & 1.31 & \\
\hline $\begin{array}{l}\text { Births outside } \\
\text { marriage (\% of } \\
\text { the total) }\end{array}$ & $1.45^{*}$ & 1.22 & 1.19 & 1.58 & 2.38 & 4.25 & 5.28 \\
\hline $\begin{array}{l}\text { Single mothers } \\
\text { per } 1000 \text { singe } \\
\text { women }\end{array}$ & $\ldots$ & $\ldots$ & $\ldots$ & $\ldots$ & 1.6 & 4.6 & $\ldots$ \\
\hline $\begin{array}{l}\text { Single mothers } \\
\text { with } 1 \text { child } \\
\text { per } 100 \text { single } \\
\text { mothers }\end{array}$ & $\ldots$ & $\ldots$ & $\ldots$ & $\ldots$ & 76.1 & 81 & $\ldots$ \\
\hline $\begin{array}{l}\text { Average age of } \\
\text { women at birth }\end{array}$ & $28.1 *$ & 28,0 & 26.97 & 25.51 & 26.73 & 28.86 & 29.81 \\
\hline $\begin{array}{l}\text { Married of age } \\
15-29 \text { per } 100 \\
\text { of age } 15-29\end{array}$ & 21.3 & 27.8 & 29.6 & 34.2 & 25.9 & 17.7 & $\ldots$ \\
\hline $\begin{array}{l}\text { Married as } \% \\
\text { of the total } \\
\text { aged } 15+\end{array}$ & 52.8 & 59.7 & 65.1 & 67.5 & 64.5 & 58.8 & $\ldots$ \\
\hline $\begin{array}{l}\text { Divorced as } \% \\
\text { of the total } \\
\text { aged } 15+\end{array}$ & 0.5 & 0.7 & 0.9 & 1.1 & 1.6 & 2.9 & $\ldots$ \\
\hline Divorces & $\ldots$ & $\ldots$ & 3675 & 6349 & 6351 & 11184 & $\ldots$ \\
\hline $\begin{array}{ll}\text { Divorces per } \\
1000 \\
\text { marriages }\end{array}$ & $\ldots$ & $\ldots$ & 50.1 & 89.2 & 96.9 & 191.2 & $\ldots$ \\
\hline $\begin{array}{l}\text { Immigrants } \\
\text { (stock) }\end{array}$ & $\ldots$ & $\ldots$ & $\ldots$ & $\ldots$ & $\ldots$ & 761,813 & $\ldots$ \\
\hline $\begin{array}{l}\text { Immigrants as } \\
\% \text { of the total } \\
\text { population }\end{array}$ & $\ldots$ & $\ldots$ & $\ldots$ & $\ldots$ & $\cdots$ & 6.9 & $\ldots$ \\
\hline
\end{tabular}

Sources: Elaboration of row data from:

1. N.S.S.G**, "Population Censuses 1951-2001", v. 2, Athens, Greece.

2. N.S.S.G**, "Vital Statistics of Greece, 1951-2006", Athens, Greece.

3. N.S.S.G**, "Justice Statistics of Greece 1971-2001", Athens, Greece.

Notes: * 1956, ** National Statistical Service of Greece.

The number of divorced people has increased considerably since 1981, reaching the $2.9 \%$ of the total population aged over 15 years old in 2001. Divorces per 1000 weddings are 191 in 2001 in comparison to 89 in 1981. The number of divorces has almost doubled during 1981-2001, a fact that shows that divorce is not a common but certainly a rapidly increasing phenomenon in Greece. 
The number of births had declined by one third during the period 1951-2001, while after 2001 the births have increased from 102.282 to 112.042 in 2006 . The crude fertility rate was reduced to the half of the 1951 figure, falling to 10 per 1000 inhabitants in 2006. Total fertility rate has fallen to 1.31 in 2001 from a level of 2.63 in 1951. Since 1981, it has fallen down to the population replacement level of 2.1 children per woman in reproductive age. The mean age of a woman in gestation is high ( 28 years old) in the first two decades of the period in consideration, falling to 27-25.5 years during next decade.

Since 1991, a considerable rise has taken place to the age mentioned above, almost reaching 30 years in 2006. In 2006, only a $5.28 \%$ of births happen outside marriage. However, the phenomenon of single parenthood is rapidly growing as births outside marriage used to be less than $1.5 \%$ during the period 1951-1981. Single mothers are still less than 5 per 1000 single women in 2001, but there is an increasing trend in 1991 (table 1). The majority of single mothers $(80 \%)$ have given birth to just one child.

The recent demographic situation of Greece, as described above, shows similarities but also differences from other European countries as illustrated in Table 2. Greece keeps exactly the $2.26 \%$ of the EU-27 population in 2001. Despite the decrease of the young population share, Greece keeps one of the highest percentages of young people together with the rest Mediterranean (except Spain), Southeastern and Central Eastern countries, compared with the lower percentages of the northwestern European countries. However, the structure by age is not in favor to southeastern Countries, as they show higher ageing than northwestern countries (except Germany). Greece, keeps the third highest ageing indicator (128.3) after Italy (141.2) and Germany (130.8).

The percentage of tertiary education women seems to be higher into the UK and to northern countries, while Greece has already higher rates than countries such as Hungary and Spain. Mediterranean countries count higher percentages of young women with tertiary education compared to the total population than northern countries. The female participation rate to labor market is lower in Greece, Italy, Spain and Hungary (37-43\%) than in northwestern countries, Portugal, Cyprus and Bulgaria (46-60\%). Among young women, the above pattern is more or less the same, but in a higher level of participation for all countries, except Sweden.

Crude marriage rate is 4.25-5.25 for most countries, while Cyprus $\left(6.80 \% \%_{0}\right)$ and Denmark $\left(6.71 \%_{0}\right)$ exceed this figure. The average age at marriage for women in 2004 is about 31 years in northern countries, 27.3-28.7 years in Mediterranean countries and Hungary, while Cyprus and Bulgaria present a slightly lower age. However, there is a common trend for all countries. Marriages still tend to take place later in life. The share of the married people is higher in Greece than in northwestern countries, despite the rapid decline in the former, during the last fifty years. 
Demographic Trends, Young People's Attitudes towards Marriage and Socio-economic Changes Related to Family Formation in Greece and in the European Union

Table 2: Demographic and social indicators for Greece and selected European countries from different regions, 2001-2006

\begin{tabular}{|c|c|c|c|c|c|c|c|c|c|c|c|c|}
\hline \multirow{2}{*}{ VARIABLES } & \multicolumn{3}{|c|}{$\begin{array}{l}\text { WESTERN } \\
\text { COUNTRIES }\end{array}$} & \multicolumn{2}{|c|}{$\begin{array}{l}\text { NORTHERN } \\
\text { COUNTRIES }\end{array}$} & \multicolumn{5}{|c|}{$\begin{array}{l}\text { SOUTHERN COUNTRIES } \\
\text { (MEDITERRANEAN) }\end{array}$} & \multicolumn{2}{|c|}{$\begin{array}{l}\text { SOUTHEASTERN } \\
\text { COUNTRIES }\end{array}$} \\
\hline & 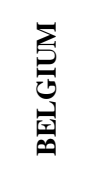 & 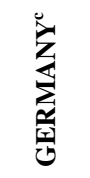 & ب & 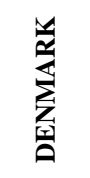 & 倠 & 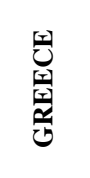 & 壳 & 沗 & 触 & 忿 & 災 & 悹 \\
\hline $\begin{array}{l}\text { Population } \\
(2001)^{\mathrm{a}}\end{array}$ & $10,3 \mathrm{~m}$ & $82,3 \mathrm{~m}$ & $59,0 \mathrm{~m}$ & $53,5 \mathrm{~m}$ & $8,9 \mathrm{~m}$ & $10,9 \mathrm{~m}$ & $57,0 \mathrm{~m}$ & $40,5 \mathrm{~m}$ & $10,3 \mathrm{~m}$ & $0,7 \mathrm{~m}$ & $8,2 \mathrm{~m}$ & $10,2 \mathrm{~m}$ \\
\hline $\begin{array}{l}\text { Population of } \\
\text { age } 15-29 \\
\text { as } \% \text { of the } \\
\text { total } 2001^{\text {a }}\end{array}$ & 18,7 & 17,3 & 19,0 & 18,5 & 18,2 & 22,1 & 19,1 & 22,7 & 22,2 & 22,7 & 21,8 & 22,2 \\
\hline $\begin{array}{l}\text { Ageing } \\
\text { indicator (2005) } \\
\mathrm{b}\end{array}$ & 101.4 & 130.8 & 89.4 & 80.6 & 99.0 & 128.3 & 141.2 & 116.7 & 107.8 & .. & 124.6 & 96.6 \\
\hline $\begin{array}{l}\text { Women with a } \\
\text { University } \\
\text { Degree } \\
\text { per } 1000 \\
\text { women of age } \\
15+^{\text {a d }}\end{array}$ & 95 & 126 & 174 & 186 & 199 & 123 & & 64 & 146 & 222 & & 104 \\
\hline $\begin{array}{l}\text { Women } 15-29 \\
\text { with a } \\
\text { University } \\
\text { Degree per } \\
1000 \text { women } \\
15-29^{\text {ad }}\end{array}$ & & 57 & 191 & 107 & 163 & 131 & & 80 & 244 & 263 & & 86 \\
\hline $\begin{array}{l}\text { Economic } \\
\text { active women } \\
\text { per } \\
100 \text { Women } \\
15+{ }^{\text {ad }}\end{array}$ & & 49 & 52 & 60 & 55 & 37 & 38 & 43 & 50 & 46 & 51 & 41 \\
\hline $\begin{array}{l}\text { Economic } \\
\text { active women } \\
15-29 \\
\text { per } 100 \text { Women } \\
15-29^{\text {ad }}\end{array}$ & & 55 & 62 & 71 & 52 & 45 & 47 & 56 & 60 & 47 & 55 & 43 \\
\hline $\begin{array}{l}\text { Marriages per } \\
1000 \text { inhabitans } \\
(2006)\end{array}$ & 4.25 & 4.54 & $4.84^{\mathrm{e}}$ & 6.71 & 5.24 & 5.16 & 4.21 & 4.61 & 4.52 & 6.80 & 4.26 & 4.42 \\
\hline $\begin{array}{l}\text { Average age at } \\
\text { marriage } \\
\left(\text { females 2004) }{ }^{\mathrm{f}}\right.\end{array}$ & $27.3^{\mathrm{i}}$ & 28.6 & $27.2^{\mathrm{j}}$ & 30.7 & 31.1 & $27.6^{\mathrm{i}}$ & $27.4^{\mathrm{j}}$ & $28.7^{\mathrm{i}}$ & 26.4 & 26.7 & 25.3 & 26.3 \\
\hline $\begin{array}{l}\text { Single } \\
\text { cohabitants per } \\
1000 \text { of age } 15+ \\
\text { ad }\end{array}$ & 52,2 & 54,8 & 60,5 & 148,9 & 0,0 & 9,5 & 7,8 & 21,4 & 0,0 & 6,5 & 34,3 & 33,6 \\
\hline $\begin{array}{l}\text { Births per } 1000 \\
\text { inhabitans } \\
(2006)\end{array}$ & 11.5 & 8.2 & 11.1 & 12.0 & 11.7 & 10.1 & 9.5 & 11.0 & 10.0 & 11.4 & 9.6 & 9.9 \\
\hline $\begin{array}{l}\text { Total Fertility } \\
\text { Rate (2006) }\end{array}$ & $1.64^{\mathrm{f}}$ & 1.34 & 1.85 & 1.85 & 1.85 & 1.38 & 1.35 & 1.36 & 1.36 & $1.47^{\mathrm{f}}$ & 1.38 & 1.35 \\
\hline
\end{tabular}




\section{K. Rontos}

19

\begin{tabular}{|c|c|c|c|c|c|c|c|c|c|c|c|c|}
\hline $\begin{array}{l}\text { Total Fertility } \\
\text { Rate (1981) }\end{array}$ & $1.68^{\mathrm{g}}$ & $1.56^{\mathrm{g}}$ & 1.82 & 1.437 & 1.630 & 2.12 & 1.597 & 2.040 & 2.130 & $2.46^{\mathrm{g}}$ & $2.05^{\mathrm{g}}$ & $1.92^{\mathrm{g}}$ \\
\hline $\begin{array}{l}\text { Births outside } \\
\text { wedlock } \\
\text { (\% of the total } \\
\text { 2006) }\end{array}$ & $31.0^{\mathrm{h}}$ & 29.96 & 43.66 & 46.36 & 55.47 & 5.28 & 18.60 & 28.38 & 31.61 & 5.6 & 50.79 & 35.59 \\
\hline $\begin{array}{l}\text { Births outside } \\
\text { marriage } \\
\text { (\% of the total } \\
2001 \text { ) }\end{array}$ & 4.9 & 12.77 & $11.5^{\mathrm{g}}$ & 35.72 & 41.19 & 1.58 & 4.43 & 4.42 & 9.49 & 0.51 & 10.29 & 7.43 \\
\hline $\begin{array}{l}\text { Single mothers } \\
\text { per } 1000 \\
\text { singe women }^{\text {ad }}\end{array}$ & & 130,7 & 215,2 & 108,2 & & & & & & & & 227,1 \\
\hline $\begin{array}{l}\text { Mean Age of } \\
\text { women } \\
\text { at birth (2006) }\end{array}$ & .. & 29.56 & 29.17 & 30.29 & 30.53 & 29.87 & $30.43^{\mathrm{e}}$ & 30.88 & 29.48 & 29.79 & 24.57 & 28.70 \\
\hline $\begin{array}{l}\text { Married of age } \\
15-29 \text { per } \\
100 \text { of age } 15- \\
29^{\text {a }}\end{array}$ & 17,5 & 13,7 & 11,5 & 11,3 & 7,4 & & & & & & & \\
\hline $\begin{array}{l}\text { Married as \% of } \\
\text { the total } \\
\text { aged } 15+\end{array}$ & 56,2 & 55,0 & 46,5 & 49,6 & 43,3 & & & & & & & \\
\hline $\begin{array}{l}\text { Divorced as \% } \\
\text { of the total } \\
\text { aged } 15+\text { a }\end{array}$ & 7,4 & 6,9 & 8,0 & 8,8 & 10,8 & 0,0 & 1,3 & & & & 4,7 & 8,8 \\
\hline $\begin{array}{l}\text { Divorces per } \\
1000 \\
\text { inhabitants } \\
(2001)\end{array}$ & 2,9 & 2,4 & 2,7 & 2,7 & 2,4 & 1,1 & 0,7 & 1,0 & 1,8 & 1,7 & 1,3 & 2,4 \\
\hline $\begin{array}{l}\text { Divorces per } \\
1000 \\
\text { marriages } \\
(2006)\end{array}$ & 650,7 & 510,9 & $548.1^{\mathrm{e}}$ & 393,5 & 445,5 & 242,2 & 201,2 & 193,1 & 500,1 & 333,8 & 452,4 & 558,5 \\
\hline $\begin{array}{l}\text { Immigrants per } \\
1000 \\
\text { inhabitants } \\
(2006)\end{array}$ & & 4,1 & 2,9 & 4,8 & 3,6 & & 0.8 & 3,3 & 0,2 & 7,4 & & \\
\hline
\end{tabular}

Sources:

${ }^{1}$ Eurostat, Population Data, retrieved from eurostat ec.europa.eu on 31.8.08

${ }^{2}$ Eurostat, 2000-01 Population Census data, retrieved from eurostat.ec.europa.eu on 31.8.08

${ }^{3}$ United Nations, World Population Prospects, Population db, retrieved from esa.un.org

${ }^{4}$ Eurostat, 2006, Population Statistics, Belgium

Notes:

${ }^{a}$ Population on 1 January 2001, Eurostat data via internet

${ }^{b}$ United Nations data

${ }^{c}$ Including ex-GPR from 1991

${ }^{d}$ Data for Education, economic active population, single cohabitants and single mothers are from 2000-1 Population Census

e 2001data

${ }^{f}$ Data for 2004 from Population Statistics 2006

${ }^{g}$ Data for 1980 from Population Statistics 2006

${ }^{h}$ Data for 2003 from Population Statistics 2006

i 2003 data

${ }^{j} 2000$ data 
Eurostat's data from the Population Census of 2000-2001 show considerable different cohabitation patterns among the regions of Europe. In Denmark, cohabitants pass above the $148 \%_{0}$ of the total population (for Sweden there is a luck of data), while Western Europe present a lower percentage of 50-60\%. The southeastern and central European countries have a percentage of about $34 \%$, while for Greece, Italy and Cyprus, cohabitation is not yet a common phenomenon, with a percentage less of $10 \%$. As an exception, Spain presents a share of $21.4 \%$ of cohabitation.

Crude fertility rate has totally declined all over Europe from an average of 18.5 in the early 60s to 10.5 per 1000 inhabitants, in 2004 (EUROSTAT, 2006). Total fertility rate is far below the replacement level (1.49), while in the early 60s, the rate was equal to 2.59. However, remarkable differences have happened among countries from several regions (Table 2).

Northwestern developed countries, except from Germany, in the middle ' 80 s and early ' 90 s, noticed a reverse in the declining trend, so that recently tend to reach the replacement level again, while countries from all other regions kept declining their fertility rates to $1.35-1.38$. Germany's exception from the northwestern patterns should be related to reunion with the ex-GPR and the low rates of the later.

Birth outside marriage pattern is quite different between Greece-Cyprus and the rest of Europe. The former countries keep the share of births outside marriage equal to $5 \%$ in 2006, while the later reach much higher figures. However, there are two important variations in the evolution of the latter countries. Firstly, the figures are not at the same level. In the Scandinavian countries, the UK and Bulgaria, half or more of the births happened outside marriage, while in the majority of the rest countries the analogy is about to $1 / 3$. Italy is an exception, with a share of $18.60 \%$. Secondly, the starting point of the phenomenon is not the same among different regions. In northern countries women started to bear outside the wedlock since the decade of " 60 s and during " 80 s the percentage of women bearing children outside marriage had reached the $35-40 \%$, while in other countries, even in western, it did not pass over the $13 \%$. Single mothers per 1000 single women, although there are missing figures for most countries, are 25-50 times higher in the selected western and northern countries.

Divorces are also considerably higher in northwestern and central European countries than in Mediterranean and southeastern countries, where Portugal and Cyprus are closer to the former group with a crude divorce rate of 1.8 and 1.7 respectively. It is noticeable that in Belgium 650.7 divorces had occurred per 1000 marriages, while in Greece the analogy is $242.2 / \%_{0}$.

Finally, immigration, a demographic factor of great importance that influences other demographic factors, is high in northwestern countries, but also in Spain, Cyprus and in Greece, as indicated in Table 1. 


\section{Behavior and Attitudes towards Emancipation, Marriage and Family Formation According to the World Values Survey (W.V.S)}

World Value Survey's data related to emancipation, marriage, family formation and fertility are retrieved and analyzed for Greece and other European countries (Table 3). According to the survey, $84.3 \%$ of the Greek people disagree with the aspect that marriage is an out-dated institution, with young people being in favor of this attitude. Among Greek people with higher educational level, $15.0 \%$ consider marriage as an out-dated institution, while in those with low educational level (elementary) the ratio falls to $9.0 \%$. In fact, the majority of the population of all European countries presents positive attitudes toward marriage. In most countries, young population indicates lower percentages, compared to the total population with Belgium, Greece and Sweden as exceptions.

The majority of Europeans were not questioned for the number of children that consider as ideal (Table 3). The data available, show Sweden and Albania with an average number of ideal children higher than 2.5. Greeks (38.4\%), Albanians $(41.7 \%)$ and $26-22 \%$ of Italians, Bulgarians and Spanish use to live with their parents, while in northwestern European countries this figure is limited to 5-12\%. Males live with their parents in a higher proportion than females. Among young people the phenomenon is extremely frequent in Albania (83.7\%), Italy $(80.8 \%)$, Spain (71.2\%), Greece (68.7\%) and Bulgaria (64.5\%).

In other words, it is a rather southern-Mediterranean phenomenon. In northern countries and in UK the proportion is less than $24 \%$, while in rest central-western European countries and Portugal, the proportion is in an intermediate level.

The importance of the leisure time is stronger in developed and more capitalized northwestern countries than in others. Greece presents a proportion much closer to the northwestern than to the southern-central countries. The proportion is higher among young people compared to the total population, showing the better living conditions and economic situation of younger generations.

Last but not least, the attitude towards the single parenthood approval of Greek and European societies is analyzed. Approval of this kind is high in Spain $(65.6 \%)$, Denmark (52.3\%), Belgium (51.6\%) and Bulgaria (46.4\%). In other countries, the approval falls about to the $1 / 3$ of the sample. Albania presents the lowest proportion of $11.6 \%$ of the total. Approval's share is stable between genders in ex W. Germany, UK, Denmark, Italy, Spain, Albania and Hungary, while it is higher among females than among males in other countries, except Portugal.

Among young people the approval is considerably higher compared to the total population, with Denmark as an exception. 
Table 3: Selected data a on attitudes and behaviour towards marriage, family formation and independence of young people for countries of different European Regions

\begin{tabular}{|c|c|c|c|c|c|c|c|c|c|c|c|c|c|c|}
\hline VARIABLES & 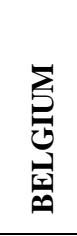 & 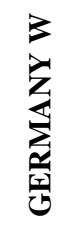 & 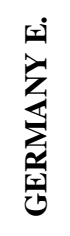 & $\stackrel{4}{9}$ & 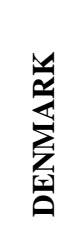 & 侌 & 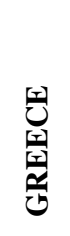 & 离 & $\frac{Z}{n}$ & 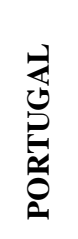 & 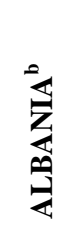 & 岕 & 氛 & 豙 \\
\hline \multicolumn{15}{|c|}{$\begin{array}{l}\text { In favour towards } \\
\text { marriage }\end{array}$} \\
\hline total sample & 69.4 & 81.4 & 82.5 & 74.1 & 85.0 & 79.6 & 84.3 & 83.0 & 825.5 & 74.4 & 91.4 & 82.1 & 82.9 & 80.0 \\
\hline male & 65.9 & 80.4 & 80.7 & 72.1 & 84.2 & 77.5 & 83.4 & 85.0 & 79.9 & 73.1 & & 80.7 & 78.3 & 78.2 \\
\hline female & 72.7 & 82.1 & 83.9 & 76.0 & 85.8 & 81.6 & 84.9 & 84.9 & 84.9 & 75.6 & & 83.3 & 86.8 & 82.6 \\
\hline age $15-29$ & 70.7 & 66.6 & 74.4 & 63.1 & 83.2 & 83.2 & 84.6 & 79.9 & 69.8 & 66.7 & 83.8 & 63.1 & 76.1 & 75.2 \\
\hline \multicolumn{15}{|c|}{$\begin{array}{l}\text { Leisure time is very } \\
\text { important }\end{array}$} \\
\hline total sample & 39.6 & 34.1 & 22.9 & 51.2 & 44.6 & 54.1 & 42.7 & 29.4 & 31.5 & 20.2 & 13.9 & 22.8 & 31.4 & 33.3 \\
\hline age $15-29$ & 43.9 & 46.3 & 35.7 & 54.3 & 46.2 & 56.7 & 53.5 & 42.2 & 39.1 & 24.9 & 22.6 & 30.5 & 44.1 & 41.5 \\
\hline \multicolumn{15}{|l|}{ Live with parents } \\
\hline total sample & 11.4 & 11.4 & 12.2 & 7.1 & 6.3 & 5.7 & 38.4 & 26.6 & 22.4 & 16.0 & 41.7 & 26.8 & 19.2 & 19.4 \\
\hline male & 13.5 & 11.7 & 17.0 & 10.6 & 8.3 & 6.7 & 42.3 & 31.8 & 26.5 & 17.4 & 49.7 & 31.4 & 22.4 & 21.5 \\
\hline female & 9.5 & 12.0 & 8.8 & 4.2 & 4.2 & 4.8 & 36.3 & 23.2 & 18.5 & 14.7 & 33.9 & 22.4 & 16.5 & 15.9 \\
\hline age $15-29$ & 49.1 & 52.6 & 44.4 & 23.4 & 23.9 & 23.6 & 68.7 & 80.8 & 71.2 & 47.9 & 83.7 & 64.5 & 57.9 & 57.2 \\
\hline \multicolumn{15}{|c|}{$\begin{array}{l}\text { Approval of single } \\
\text { parenthood }\end{array}$} \\
\hline total sample & 51.6 & 30.6 & 29.8 & 30.2 & 52.3 & 31.7 & 31.1 & 27.6 & 65.6 & 36.6 & 11.6 & 46.4 & 38.5 & 37.9 \\
\hline male & 47.5 & 30.3 & 24.0 & 30.8 & 52.4 & 26.9 & 28.4 & 27.9 & 65.8 & 39.2 & 11.5 & 44.5 & 39.0 & 36.7 \\
\hline female & 55.5 & 31.0 & 34.7 & 30.7 & 52.3 & 36.3 & 32.5 & 27.4 & 65.4 & 34.3 & 11.7 & 48.2 & 37.9 & 39.0 \\
\hline age $15-29$ & 54.4 & 45.1 & 40.5 & 42.1 & 52.5 & 24.5 & 32.9 & 26.1 & 79.6 & 50.1 & 18.4 & 56.6 & 45.2 & 43.0 \\
\hline
\end{tabular}

Source: World Value Survey, 1999-2004

${ }^{a}$ As \% of the total

${ }^{b} 2002$

\section{Recent Research Evidences about Attitudes towards Marriage and Family Formation in Greece}

As W.V.S was contacted almost a decade before, while relative matters are rapidly changing, some more recent research can be added to our work. Data derives from a specific survey conducted by the staff of the Aegean University Department, Lesbos, Greece, in April and May 2006. The aim of this survey was to collect data on the attitudes of University female students towards marriage, fertility and divorce. The size of the sample came up to 220 unmarried female students in all faculties and years of attendance. A stratified simple random procedure was used as a sampling method. The department and year of attendance were used as stratified factors, while 
for the allocation of the sample among strata sampling with probability proportionate to the population size was used.

As the selected sample includes students coming only from the Aegean University and not from all universities all over Greece, the results of the present survey should be generalized to national level with relative attention. Data were selected by experienced and well-trained students of the Aegean University by interviewing each sample unit. The fact that University of the Aegean students come from different places all over Greece allows generalisation of the results to national level with a certain degree of representation. Concerning the size of the sample, we think that it is more or less sufficient, as the population seem to present a limited variation for basic variables. If 1000 sample units used in W.V.S for Greece are sufficient for the representation of the total population of Greece, it is quite logical that 220 units are sufficient for the female university students. The compatibility of the survey results with these of W.V.S will be one more proof of the survey's reliability. A questionnaire of 43 mainly closed-type questions was filled in by every sample unit.

The average age of the 220 students was $20.54 \pm 0.24$ years, ranging from 18 to 30 . Their average year of attendance was 2.5. Their place of origin were mainly from the two Metropolitan areas of Greece (37\%) and other cities with at least 25,000 inhabitants (another 37\%), while students coming from other places came third in frequency $(26 \%)$.

According to the survey, $81.8 \%$ of the students were in favor to marriage, while $18.2 \%$ were against, a result fully compatible to those of W.V.S. The three basic reasons that led a woman to marriage, according to students' opinion, were emotional reasons $(66.4 \%)$, the belief in the institution of marriage $(59.5 \%)$ and social (except religious) reasons $(46.4 \%)$. Financial or religious reasons were of lower importance.

On the other hand, more than half $(59.6 \%)$ declared that they would mostly prefer cohabitation rather than marriage and almost all agree (91.4\%) that, nowadays, young people take the decision to get married with more difficulty than in the past. Most of the students believe that they would choose cohabitation as an alternative $(87.5 \%)$, while, among those who declared in favour of marriage, about half $(53.4 \%)$ of them stated at the same time a preference for cohabitation. The association test between attitudes towards marriage and attitudes towards cohabitation indicated high statistical significance (Chi-square $=15,804, \mathrm{df}=1, \mathrm{p}=0.00<0.001$ ).

The association of certain factors with the attitudes towards marriage was tested using separate Chi-square tests (Table 4). The influence of non-permanent work on the decision to getting married was significantly associated with young students' attitudes towards marriage $(\mathrm{p}<0.05)$. High statistical significance appeared to their mothers' educational level $(\mathrm{p}=0.004<0.01)$ and extremely high statistical 
significance appeared in their preference for cohabitation instead of marriage and in their intention to undertake marriage obligations $(\mathrm{p}=0.00<0.0001)$.

The real meaning of "to undertake marriage obligations" here is the intention to spent time and money for family and children instead of spending them for themselves. The statistical association of attitudes towards marriage with the size of the city of origin, with the source of income and with the students' opinion about the negative influence of career on marriage decision remained unclear $(0.05<\mathrm{p}<0.10)$.

Table 4: Chi-square test results between "attitudes toward marriage" and several categorical explanatory variables concerning female students $(N=220)$

\begin{tabular}{|c|c|c|c|}
\hline Variable & $\begin{array}{c}\text { Chi-square } \\
\text { value }\end{array}$ & $\begin{array}{c}\text { Degree of } \\
\text { freedom }\end{array}$ & Significance \\
\hline Mothers' educational level & 13.35 & 3 & 0.004 \\
\hline Size of city of origin & 5.06 & 2 & 0.08 (unclear) \\
\hline Family type & 2.41 & 2 & n.s \\
\hline Fathers' educational level & 3,50 & 4 & n.s \\
\hline Source of income & 5,195 & 2 & 0.074 (unclear) \\
\hline Size of income & 1.41 & 3 & n.s \\
\hline $\begin{array}{l}\text { Cohabitation preference vs } \\
\text { marriage }\end{array}$ & 15.80 & 1 & 0.00 \\
\hline $\begin{array}{l}\text { Availability for marital } \\
\text { commitments and obligations }\end{array}$ & 71.94 & 2 & 0.00 \\
\hline $\begin{array}{l}\text { Students' opinion about negative } \\
\text { impact of career on marriage } \\
\text { decision }\end{array}$ & 6.68 & 3 & 0.083 (unclear) \\
\hline $\begin{array}{l}\text { Influence of non-permanent work } \\
\text { on marriage decision }\end{array}$ & 7.53 & 3 & 0.05 \\
\hline $\begin{array}{l}\text { Students' opinion about the } \\
\text { measures that the State has taken to } \\
\text { encourage young people to get } \\
\text { married. }\end{array}$ & 2.56 & 2 & n.s \\
\hline
\end{tabular}

Notes: The values of the variable "attitudes toward marriage" were "in favour" and "against" values.

The next research question was whether attitudes towards marriage by female university students, have an impact on fertility. First of all, it should be mentioned that most of the students would like to bear two children (59.1\%), while $29.5 \%$ of them three or more. It is interesting that $2.3 \%$ of the students would rather have no children at all. These results are similar to those found by the W.V.S. Attitudes against or in favor of marriage are highly associated with the number of children that students would like to have (Chi-square $=28.24, \mathrm{df}=3, \mathrm{p}=0.0<0.0001$ ). No student in favor to marriage likes to bear no child.

No Statistical significance appeared between the cohabitation preference of students and the number of children they would like to have (Chi-square $=5.9, \mathrm{df}=3$, $\mathrm{p}=0.116>0.05)$. However, the ratio of students who preferred cohabitation was 
decreasing as the number of children was increasing. It is characteristic that all students who would rather have no children were in favour of cohabitation, $75 \%$ of those who would like to have 1 child were in favour of cohabitation, whereas the percentage fell to $56.9 \%$ for those who declared that they would like to have three or more children.

It is interesting that $27.7 \%$ of the total of students found the perspective of having children out of marriage impossible, while an additional part of $31.8 \%$ stated that they had never thought about that before, leaving a considerable $40.5 \%$ who found possible to have children without getting married. Attitudes towards marriage were strongly associated with the perspective of having children outside marriage (chisquare $=9.86, \mathrm{df}=2, \mathrm{p}=0.007<0.01$ ). It should be noticed, that among those who were against marriage, $62.5 \%$ had considered the perspective of having children outside marriage possible, while the percentage in favor of marriage fell to $35.6 \%$.

Completion of graduate studies and subsequent pursuit of postgraduate studies were the first priority for the majority of students $(89 \%)$, while joining the labor market was the first priority for $9.6 \%$ of the total. Only $0.9 \%$ had as a first priority getting married and having a family, an intention expressed by all students independently the year of attendance. These preferences resulted to an average age of marriage in 28.34 years, a figure close enough to the official data (29.69). Attitudes to marriage, as expected, were highly associated with the most suitable age for marriage, as seen by female students (chi-square $=11.08, \mathrm{df}=2, \mathrm{p}=0.004<0.01$ ). No student against marriage considered the age of 24 years old or less proper for marriage.

\section{Socio-economic Transformations in Greece Related to Demography Evolution and Attitudinal Changes}

The civil war, that took place in Greece in 1946-49, extended the irregularity of the World War II and of the position by the Germans- Italians to almost a decade. The end of ' 40 s found Greece as still an agricultural society. Most people lived in villages and small towns and the $48,1 \%$ of the economically active population occupied in the primary sector (table 1), while in the northwestern European countries the industrialization had been greatly integrated far before the World War II period (Rontos, 1995).

As agricultural units in Greece used to be small family holdings, the desire for children, especially of males, was high as their utility for them was also high for the farms' activities. The fertility analysis of Becker (1960) based on the children utility for parents and the new developments about human capital and the family, as unit of production (Becker, 1976, Becker and Tomes, 1976), seems to make sense in an agricultural economy of this kind. Deep religion beliefs were in favor to marriage and fertility, while abortion and divorce were totally not accepted. A woman's basic role was to support her husband, bear children and also work in the fields when needed. Her marriage match was decided by the parents who gave a dowry to the 
man before marriage. Family follows the broader co-residential type, including grandparents, parents and grandchildren.

After the 1951-61 decade of re-organization, economy and society was gradually transformed to an industrial one. The change in the structure of economic activity was extremely rapid, so that in 2001, the economically active population in primary sector fell to $13.0 \%$ of the total (Table 1). As industry was concentrated into the main metropolitan areas of Athens and Thessaloniki, a tremendous internal migration toward these areas took place, mainly in the decades of ' 60 s and ' $70 \mathrm{~s}$. As a result, $37 \%$ of the total population was gathered in these two areas in 1991 (Table 1). The new classical theory (Isaac, 1947) for the labor movements, adapted by Governments, was responsible for this evolution.

The internal migration flows by farmers or workers provoked population changes among regions, followed by new economic activities in the destination regions, due to the increasing needs of the new population (Birg, 1982). This circle of economicdemographic interaction was present in Greece up to the end of the ' 80 s.

The fact that industrialization and urbanization led to small nuclear families with less children, decreasing birth rates is almost a rule in the practice of several countries (Dooghe, 1994). Research work has clearly found out that the higher the urbanization level the lower the preference for marriage at an early age for family (Montgomery et al, 2003, Choe et al, 2004). Changes in consuming patterns, woman's role, the cost of children, are some of the reasons that cause new family formation in an urban- industrial society. (Kyriazis, 1992). The new life-style gives a dominant role to the work and promotes the consumption of time and money for entertainment.

In addition to the extremely high internal migration, during ' 60 s and ' 70 s, Greek society and economy faced a wave of emigration towards the western European countries, mainly Germany and U.S.A. During 1955-77, 1.021.961 Greek, mostly young people, permanently and 1.196 .601 temporarily emigrated (National Statistical Service of Greece, 1972 and 1980). The luck of such a huge amount of young people had a tremendous direct and indirect negative influence on the size of young people, on the number of marriages and births and on the population ageing.

Legal and social changes have gradually established the liberation of the woman, her rights to self determination towards marriage and childbearing, her rights to education, career and finally their equality to man. The growing participation of women, especially of the young, in the tertiary education and to the labor market in Greece, during the last fifty years, was presented in Table 1. As a result, marriage and family formation have been affected negatively by the changing economic roles of men and women (Kalmijn, 2007). Education and work led the age of woman at marriage and at first birth to be at 30 or more, in almost all over Europe. 
Concerning education, marriage and family formation are influenced not only by the educational level of young female people, but also by their mothers' level. As the demographic trends with less marriages and declining fertility were common in Europe, northwestern countries took policy action to support family, childbearing and single parenthood. As a result, since the middle of ' $80 \mathrm{~s}$, a reverse demographic pattern is emerging in these countries with growing fertility, tending to reach the reproduction limit of 2.1 children per woman in reproductive age. Single parenthood is already a common situation in countries as UK, Sweden and Denmark, where half or more of births happen outside marriage. On the other hand in Greece, there is a certain lack of strategy in the social policy and any measures taken have been partly or inefficient. In general, demographic policy and research is of low priority in Greece, as family expenditures of every type was $0.1 \%$ of the GDP in 1993, while the average for Europe is $3.5 \%$ (Mousourou, 2002). In fact, integrated and strong policy for the family and fertility has never been implemented in Greece.

Since '90s, some new national and international changes influence young people's demography, marriage, family formation and fertility. Greece, despite the positive attitudes towards marriage shown by the W.V.S and the specific survey results, marriage and child bearing is of low priority after education attendance, work and are associated with the unwillingness to undertake the obligations arising from marriage.

This is a really important fact that explains the change of attitudes towards marriage and family, recently recognized by research. As Seltzer et al (2005) points out "individualization and secularization of western societies as a commonly invoked explanation for changes in marriage". The present study has also shown the high and increasing importance that Greek and other European young people give time to leisure. Actually, current demographic trends and social-economic developments give evidence that Greece is passing to the fifth phase of its demographic transition (Notestein, 1942, Reynolds and Mansfield, 1999).

Labor market in Greece is characterized by the lack of vacancy, especially for permanent positions, unemployment, especially of young people of 20-24 years old (unemployment rate $22.6 \%$ in 2008), low starting salaries and often positions without social security benefits. Furthermore, the non permanent forms of employment recently introduced in the Greek labor market were pointed out as a basic factor associated with the attitudes towards marriage by young female university students. This finding is also identified as important by Oinonen (2004) for both Spain and Finland.

These problems that Greek young people faced, in combination to the luck of any support from the State, led them into living with their parents for a long time, postponing their emancipation. As revealed by the W.V.S's data, living with parents in a great proportion, especially for young people, is mainly a southern pattern. In a less extend, all other countries face this problem, except from the northern countries 
and UK. The later countries have established a culture supported by the state and the parents for the emancipation of young people, leaving their parent's home at an early age.

In Greece, as indicated by Mousourou (2002), the constitution of family works as a defending mechanism of social protection for their members. In general, family networks as described by Coleman $(1988,1990)$ are very strong in Greece, which substitute official institution not only for children growth and protection but also for finding a work (Chtouris et al, 2005, Jones et al, 2008).

Moreover, a factor that influenced demography and family matters, after 1990, is the transformation of Greece from an origin to a destination country for migrants, counting 761.813 immigrants in 2001, mainly from Albania (almost 50\%), Bulgaria, Poland and Ukraine. As a result, population was enforced mainly with young people, marriages stopped falling and births have risen by 10.000 during 2000-2006 period. In general, a comparative examination of immigration flows in the European countries indicates that higher rates in northern countries, UK, Spain and Greece help the demographic trends to be improved.

Attitudes towards marriage and family formation, in Greece and in Europe, give more explanations and light on the possible future behavior about the examined matters. The attitudes towards marriage are positive for the majority of the population all over Europe. The above attitudes are totally against the demographic trends and the actual behavior as developed in the analysis section. The explanation is that attitudes towards marriage are not based on the legal, religious and social pressure of the past but on the social values that are weak and they are not transformed in behavior, under the real pressure of economic environment and the trends towards cohabitation and single parenthood (Wilson, 2002). Differences between attitudes and final behavior are a central and complicated issue, addressed in several studies (Ajzen and Fishbein, 1977, Martin and Parashar, 2006).

The specific survey also shows that the majority of young female students are in favor of marriage, confirming the W.V.S's results and at the same time giving more evidence for its accuracy and sufficiency. However, the reasons that, nowadays, lead a woman to marriage are different in comparison to the past, despite the economic and religious reasons (Van Poppel, F. and Nelissen, J., 1999) and its consideration as a mean of social maturity and economic independence (Mooney-Marini, 1978).

Young female students of the present research consider emotional reasons as a good reason to get married, while they also express their belief in family as a social institution. It is obvious that marriage, in contemporary Greece, is regarded as an institution and as relationship (emphasis upon the emotional aspects of marriage), a situation described by the literature (Reynolds and Mansfield, 1999). 
Although the majority of students were in favor of marriage, they partly kept a reserve about their future behavior, as more than half have stated that in the future they could prefer cohabitation instead of marriage.

Attitudes against marriage are associated with the desire of young educated women in Greece to have few or no children. This is consistent with the previous discussion and assumes that negative attitudes towards marriage are also against family and child bearing, as Pinelli and Cesari (2005) found in the southeastern European counties.

Towards the same direction is the finding that negative attitudes towards marriage are strongly associated with the students' approval of having children out of marriage. The majority of students against marriage appeared to be in favor of the prospect of having children without getting married and vice versa. Generally speaking, a great part of young students seem to have a negative attitude towards single parenthood, another part has a positive attitude and some others to have never thought of this issue. The triple pattern found by the present survey is verified by the W.V.S (1999).

In general, the results from both survey's employed in this study are reflecting exactly the following central point: at first sight, Greek society seems to be traditional as far as marital attitudes are concerned, but new patterns are gradually being accepted, especially by young educated people.

\section{Conclusions}

The study of family issues, especially for Greece, could contribute to social research, exploring the particularities or similarities with countries in all European regions, as well as to define certain geographical patterns of the type North-South or West-East. And this is possible, as in an European and international environment with fewer and delayed marriages, decreasing fertility rates, changing patterns in family formation and the dissolution of marriage are characterized by the rapid expansion of cohabitation, single parent families and increased divorce rates.

Demographic trends in Greece follow a rather southeastern European pattern, which, compared to the northwestern one, it is characterized not only by the higher shares of young people, but also, by the higher ageing rates, an increasing but lower average age at marriage, lower share of cohabitants, considerably higher shares of young people living with their parents, lower and steadily decreasing fertility rates, considerable lower share of births outside marriage, and finally, lower rates of divorces.

Northwestern countries have managed to increase their decreasing fertility rates, since the middle of ' $80 \mathrm{~s}$, after a strong and systematic policy including support to single parenthood and generally to births outside marriage. Germany does not follow 
this reverse pattern. In general, Germany indicates some differences to the liberal northwestern pattern, mainly as a result of the different trends that come from the ex-GPR. UK also seems to follow the northern countries, where, despite their grouping with the western countries for analytical reasons, trends are stronger and closer towards liberation concerning family issues.

Migration is rather a regional matter where countries as Germany, Sweden, Denmark, Spain and Greece attract immigrants from neighboring countries. Moreover, migration seems to be the key for the population stability in Europe, as fertility is lower than the replacement level and natural increase has became negative, even in countries with strong and proper policy implementation.

Greece, as well as, Cyprus presents a considerable particularity concerning the above-mentioned, rather traditional, southeastern pattern. Births outside marriage are an increasing, but yet, an extremely restricted phenomenon, showing a constant pattern, connecting births with marriage. In general, Greece seems to keep more elements of the traditional family formation patterns than other more liberal European countries, due to the fact of the late industrialization and urbanization phase, i.e. in the World War II.

However, as the socio-economic transformation has been characterized by the rapid changing role of woman, the new labor market trends and the changing origindestination pattern of migration flows, the family formation attitudes are recently changing, while Greece presents elements of the fifth phase of the so called "demographic transition". Surveys' results, used by the present study, give evidence that Greek society and especially young people are still in favor of marriage as a value, as well as, of a larger number of children. At the same time, young people are open to cohabitation, while, marriage and childbearing is of low priority to them compared to education attendance, labor market entrance and career. They express their unwillingness to marriage obligations and a great number of them keep staying with their parents postponing their emancipation.

The key point for the future evolution will be the role of the state, that, up to now it has been far away from the implementation of an integrated strategy to support marriage and family formation of other kinds, fertility and young peoples' emancipation, leaving family networks to cover the relative needs. Only by strengthening the family formation and the fertility rate, will the country manage to renew its population, as this seems to have started in countries as USA and Denmark, after the implementation of a consistence and long-term policy action. 


\section{References}

Adams, Bert (2004) "Families and Family Study in International Perspective", Journal of Marriage and Family 66:1076-1088.

Ajzen, Icek and Fishbein, Martin (1977) „Attitude-behaviour relations: A theoretical analysis and review of empirical research" Psychological Bulletin 84(5): 888-918.

Becker, Gary S. (1960) “An Economic Analysis of fertility", in "Demographic and economic Changes in developed countries", Princeton: University Press for the National Bureau of Economic Research.

Becker, Gary S. (1976) "The Economic Approach to Human Behaviour", Chicago: University of Chicago Press.

Becker, Gary S. and Tomas, Niger. (1976) Child Endowments and the Quantity and Quality of Children", Journal of Political Economy 84:143-162.

Birg, Herwig (1982) "On the interaction of job creation, migration, natural population increase within the framework of a dynamic demoeconomic model", Environment and Planning . 14(9):1141-1153

Choe, Minja Kim, Retherford, Robert D., Kim, Seung Kwon (2004). Low fertility in South Korea: Patterns and Prospects, paper presented at the Annual Meeting of the Population Association of America, Boston, Massachusetts, April.

Chtouris Sotiris, Zissi Anastasia, Papanis Efstratios and Rontos Konstantinos (2006) "The state of youth in contemporary Greece", Young, 14(4): 309-322.

Coleman, James S. 1988 "Social capital in the creation of human capital", American Journal of Sociology 94 (Suppl) :95-120

Coleman, James S. 1990. "Foundations of Social Theory” Cambridge, MA: Belknap Press of Harvard University Press.

Dixon, Ruth B. (1971) "Explaining cross-cultural variations in age at marriage and proportions never marrying" Population Studies, 25(2):215-233.

Dooghe, Gilbert (1994) "Social Aspects of Ageing" in "Social Aspects and Country Reviews of Population Aging", Economic Studies no 6, United Nations.

Fussel, Elizabeth and Palloni, Alberto (2004) "Persistent Marriage Regimes in Changing Times", Journal of Marriage and Family 66:1201-1213.

Hallett, Marry Beth \& Gilbert, Lucia Albino (1997) "Variables Differentiating University Women Considering Role-Sharing and Conventional Dual-Career Marriages" Journal of Vocational Behaviour 50: 308-322.

Heuveline, Patrick and Timberlake, Jeffrey M. (2004) "The Role of Cohabitation in Family Formation: The United States in Comparative Perspective", Journal oOf Marriage and Family 66:1214-1230.

Isaac, Julius (1947) "Economics of Migration” N.Y: kegan Paul Trench, trubner \& co Ltd publishers

Johnson, S. J. \& Jaccard, James (1981). "Life Structure Decisions: Factors Related to CareerMarriage priorities in College Youth" Journal of Applied Developmental Psychology, 1: 277-295.

Jones, Nikoleta, Malesios, Chrisovalandis, Iosifidis, Theodoros and Sofoulis Costas (2008), "Social Capital in Greece: Measurement and Comparative Perspectives", South European Society and Politics 13(2): 175-193.

Kalmijn, Mattjijs (2007) "Explaining cross-national differences in marriage, cohabitation, and divorce in Europe, 1990-2000", Population Studies 61(3):243-263. 
Demographic Trends, Young People's Attitudes towards Marriage and Socio-economic Changes Related to Family Formation in Greece and in the European Union

Kerpelman, Jennifer L. (1999) Young Adult's Anticipated Identity Importance of Career, Marital and Parental Roles: Comparisons of Men and Women with Different Role Balance Orientations. Sex Roles, 41: (314).

Kyriazis Nota (1992) "The population reproduction-Theory and research", Athens, Greece: Gutenberg Editions

Manning, Wendy D., and Smock, Pamela J. (2005) 'Measuring and Modelling Cohabitation: New Perspectives from Qualitative Data', Journal of Marriage and Family, 67 (Nov 2005):989-1002.

Martin, Steven P., and Parashar, Sangreeta (2006) 'Woman's Changing Attitudes toward Divorce, 1974-2002. Evidence for an Educational Crossover', Journal of Marriage and Family 68:29-40.

Merino Rafael and Garcia Maribel (2006) "Emancipation enlargement and the acquisition of autonomy by young people in Catalonia", Young 14(1):33-47.

Montgomery, Mark R., Stren, Richard, Cohen, Barney and Reed, Holly E. (2003). "Cities Transformed: Demographic Change and its Implications in the Developing World", Washington, D. C: National Academies Press.

Mooney-Marini, Margaret (1978) "The transition to adulthood: Sex differences in educational attainment and age at marriage", American Sociological Review, 43:483507.

Mosher, William D. (1988) "Fertility and family planning in the United States: insights from the National Survey of Family Growth", Family Planning Perspectives 20 (5):207-217.

Moussourou, Laoura (2002) "Family and State of Welfare", in "Families and State of Welfare in Europe”, Maratou-Alibranti Laoura Ed., National Center of Social Research, Gutenberg Press, Athens.

Munoz, Perez F. (1995) "Reproduction and marriage in Spain 1970-1990" Summary in English of the original in Spanish in Review of International Sociology, 11: 199-237 retrieved from www.ncbi.nlm.nih.gov.

National statistical Service of Greece (2008), Primary data from the Labor Force Survey retrieved by the www.statistics.gr on 16.9.2008.

National statistical Service of Greece (1972), "Statistical Year Book of Greece 1971", Athens, Greece.

National statistical Service of Greece (1980), "Statistical Year Book of Greece 1979", Athens, Greece.

National Statistical Service of Greece (2005). "Vital Statistics of Greece". Athens, Greece.

National Statistical Service of Greece, (1981, 1991, 2001) "Statistics of Justice", Athens, Greece.

National Statistical Service of Greece, (2006) "Vital Statistics of Greece", Athens, Greece.

Notestein, Frank W. (1945) "Population-The Long View" in "Food for the World", Chicago: University of Chicago Press.

Oinonen, Eriikka (2003) "Extended present, faltering future", Young 11(2):121-140.

Oinonen, Eriikka (2004) "Starting the first family", European Societies 6(3):319-346.

Pinnelli, Antonella and Di Cesare, Mariachiara (2005) 'Human fertility: sociodemographic aspects', Contraception 72: 303-307.

Reynolds, Jenny and Mansfield, Penny (1999) "The effect of Changing attitudes to marriage on its stability", in "High Divorce Rate: The State of the Evidence on Reasons and Renemies:, Lord Chancellor's Department, Research Series, 1(2).

Rondriguez, Hilda (1998). "Cohabitation: A snapshot. Center for Law and Social Policy", retrieved frominfo@clasp.org . 
Rontos Kostas, (1995), "Regional Structure of Services in Greece and into the European Union", in Kostas Koutsopoulos (ed) "Interscience Approaches to Regional programming”, pp.91-122, Athens, Greece: Regional Science Association, Greek Sector.

Seltzer, Judith A., Bachrach, Christine A., Bianchi, Suzanne M., Bledsoe, Caroline H., Casper Lynne M., Chase-Lansdale P. Lindsay, Diprete, Thomas A., Hotz, V. Joseph, Morgan S. Philip, Sanders, Seth G. and Thomas Duncan (2005) 'Explaining Family Change and Variation: Challenges for Family Demographers', Journal of Marriage and Family 67: 908-925.

Tomes, Nigel (1985) "Childlessness in Canada 1971: a further analysis", Canadian Journal of Sociology 10 (1):37-57.

Van Poppel, Frans and Nelissen, Jan (1999) "The Proper Age to Marry : Social Norms and Behaviour in Nineteenth-Century Netherlands", The History of the Family 4 (1):51-75.

World Values Survey Association (1999). World Values Survey for Greece, 4th wave, data retrieved from the www.worldvaluessurvey.org. 